\title{
ANNUAL REASSESSMENT VERSUS THE UNEARNED INCREMENT TAX
}

\author{
By Alfred D. Bernard, LL.B., \\ Attorney at Law, Baltimore, Md.
}

The basic reasons for the taxation of real estate for local purposes are that the local government especially safeguards the local property, its expenditures are largely beneficial to real estate, and in its expenditures more or less attracts a community, which becomes prosperous under good government and wise expenditures; that the community grows, thus creating a demand for land; that the real estate assumes a value which is given to it by the community; that the growth of the community creates constantly new and changing values, shifting utilities for land, and in many instances increases the values; that the land being a tangible expression of the power of the community to utilize, land may be said to have a community value, which it has received from the local government, and therefore should be taxed.

On this basic proposition, the average intelligent subjects of the United States are apparently unanimous. But there is a great diversity of opinion as to whether real estate should bear the burden of local taxation or whether the tax should be confined to the land with a scaling valuation for improvements, or whether the improvements should be eliminated altogether. Moreover there are advocates of taxing what is termed the unearned increment, which, if the writer correctly understands, is intended to exact from the landowner a portion of the difference between the market values of his land at intervals, on the theory that the increment attaching to the land is through no effort of the owner, but through the growth of the community.

Assuming that there is such a thing as an unearned increment attaching to land, is it fairly a subject of taxation? And if it is a subject of taxation, is it fair to tax this so called unearned increment, and also tax the land at the various periods of reassessment at the then market value of the land? And if this proposition shocks the spirit of fairness, will an annual reassessment be a fair substitute for the unearned increment tax? 
The fundamental of all taxation is equality. Quoting from the constitution of Maryland, Article 15 of the Declaration of Rights, following the proposition laid down by Adam Smith in his Wealth of Nations, published originally in 1776, ". . . every person in the state or person holding property therein ought to contribute his portion of public taxes for the support of the government, according to his actual worth in real and personal property."

Before attempting to tax the unearned increment, we should make a practical effort to see if we can ascertain what it is, and a few illustrations based on fact may be timely.

In 1898 , Smith bought 1,000 shares of Atchison common at $\$ 13$ per share, and locked it up in a safe deposit box. For a few months after his purchase it fluctuated around buying price, but it never got below $\$ 13$, and when he sold out at one hundred per share, the contribution of the public and the very excellent management of the road by way of unearned increment amounted to $\$ 87,000$ less commissions.

The same day Brown bought a small lot on $\mathrm{H}$ Street, improved by an old dwelling, for $\$ 10,000$. It was hard to rent at $\$ 500$, and Brown studied the situation, and concluded that the conversion of this property into a modern shop would be a wise move. He, accordingly, spent $\$ 3,000$ in introducing modern heating, plumbing, lighting, a swell store front and creditable decorations. When he finished his repairs he had $\$ 13,000$ invested in the property. By the exercise of patience and tact, he finally succeeded in getting a tenant who took a long lease at a scaling rent starting at $\$ 600$ and advancing $\$ 100$ a year, so that, in 1909 , the property was producing $\$ 1,600$ per annum; the pioneer tenant in the block was doing a splendid business, and other shops had followed him; the utility of the block had completely changed in ten years, and the tenant, feeling that his business was growing rapidly, bought the property from Brown for $\$ 30,000$, the tenant and Brown both agreeing that the property was actually worth $\$ 20,000$ at the time of the purchase, but Brown thought that it would ultimately go to $\$ 40,000$, the seller discounting, and the buyer purchasing the future increment.

In this instance, the daring Brown in risking his capital, the energy of the tenant in pulling business another block, the contribution of the ever increasing public by way of the so called unearned increment produced $\$ 17,000$. 
The day Smith sold out he met a friend who had a perfectly sure thing in beer selling around " 80 " but going to " 120 " before spring, and Smith bought 1,000 shares. In three years that concern went into the hands of a receiver, and Smith lost $\$ 70,000$.

One more incident. The day Brown sold out he felt pretty chesty, and took his wife out in a "demonstrator." They passed a very swell looking suburban plot, beautifully shaded, with a large compelling house, on which was a bargain sign. The property was being shown to a prospect, so they went in. The wife raved over the shade trees, thought the outlook a dream, and the perfume of the hay field opposite the one thing necessary to complete her happiness. Twenty thousand dollars would buy it with five acres of ground and the house cost over $\$ 20,000$ to build. It was a bargain, how could the owner be so foolish as to part with it? Brown bought the property, spent $\$ 2,000$ renovating the house, and installed Mrs. Brown in her new paradise, opposite the hayfield view.

The next spring the owner of the hayfield sold it, and before the summer was over a row of two story houses of exasperating monotony was shutting out the beautiful view, and the perfume of the hayfield was punctuated by an odor of fresh plaster and burning pitch. Mrs. Brown had hysterics and her physician ordered her out of the house with dire penalties for disobedience. Brown sold out for $\$ 7,900$, the value of the lot; the mansion house was torn down and two story houses erected. The contribution to this unearned increment was minus.

Incidents like these are the practical premises from which the thoughtful student of economics must draw his deductions. Smith's friends called him a master of finance, until he bought beer common, then his friends said "____. Brown was regarded likewise by his friends before and after.

Now if the city exacted a part of Smith's profit on the Atchison deal, and Brown's profit on the real estate deal, ought it not fairly return Smith a share of his loss in beer common, or Brown's loss because he could not see that the suburban property he had purchased was obsolete? Such an argument brings the blush of shame to the most ardent student of social economics, yet it is the fundamental principle of taxation that a man should pay taxes on his worth in real and personal property.

But, again, the unearned increment taxer is willing to let Smith go free, on the theory, perhaps, that his profit being a gamblcr's 
profit, he is liable under the law of averages to lose out on his next deal, or perhaps he is not able to fix the community value attaching to a stock jobbing transaction. Can he fix it on the realty deal?

Let us analyze this transaction. Brown's paper profit was $\$ 17,000$. Against this should be charged the taxes, repairs and interest on his original capital and the fund should be credited with the rent; so that the actual profit was approximately $\$ 15,000$, of which $\$ 5,000$ was increment, and $\$ 10,000$ a tax the tenant paid to the landlord for the privilege of being owner of the good will of the place.

If this increment were solely the contribution of the community, why does one merchant succeed and another fail? If this increment is solely the contribution of the community, why do values shift with shifting utilities? And why in the average large city have the increments attaching to suburban property been largely if not totally offset by the shrinkages in the inside residence districts?

We believe there is an increment attaching to land in certain locations due to the natural growth of the community, which affects its selling value, but the community rarely localizes it. The best corner lot in a given city is seldom the geographical centre or even the centre of population, but is largely due to the enterprise of individuals, the power of advertising, and the consent of the community to be drawn to a given point for a purpose, and that purpose is usually a belief that an advantage may be gained at the particular point.

If ten merchants would open as many large department stores at spaced distances on Fifth Avenue in New York, between Union Square and Central Park, with ample capital and make generous advertising expenditures, the chances are, the five to the south would fail; but if the ten would agree to locate at or near Broadway and Forty-fourth Street, it is more than likely that the whole retail business district of New York would be shifted twelve blocks north; land values in the new district would be quadrupled and the present district would be cut in half. The community would contribute to the increment of the new section by seeking it to buy goods, but the moving factors in the enterprise would be the persons who risked vast sums of money to create the new district.

The owner of a farm on Long Island sees the city grow steadily towards his property. So long as it is a farm its highest market value is expressed in its capacity to produce; hence its utility fixes its highest market value. As the city approaches it, it assumes a 
potential or speculative value, in that it will soon be ready for a subdivision, and its value increases beyond its farming utility value. Yet it is not ready for the market and the chances are that a subdivision would be a complete failure. But with the growth of the city it becomes ready for suburban development and the owner sells out to a promoter, who interests capital and capital takes a business risk and is successful. The increment undoubtedly attached to the farm with the growth of the city, but until it was developed it was a farm, and the development required individual effort, capital and management to make it successful. The owner may or may not have made a profit, notwithstanding the apparent paper profit the sale showed on the original cost, as it is a well known fact that many a rural tract held for development has been held so long that the paper profit did not equal the interest the owner would have realized if the cost of the property had been invested in government bonds at 2 per cent.

One more illustration before passing to the main subject. The owners of the respective corners of the block on Main Street erect imposing sky scrapers, thus increasing the traffic on Main Street and the inside lots double in value. This must surely be an increment due wholly to the community. But after the office buildings are twenty years old, the owners find that they will not pay their fixed charges, and they have erected monuments to their own asininity. The owners of the lots improved by the old shacks are offering expressions of sympathy but no rent. The gains in the middle of the block are largely offset by the losses on the corners.

This brings us to the main argument.

If there is any increment attaching to land which may be said to be unearned, it does not attach over night, but is a growth, which is the expression of the growth and buying power of the community. No one would advance the theory that a successful merchant should give up a share of his annual profit to support the local community, but all will agree that he should contribute an equal percentage of his worth, whether it be expressed in real or personal property, and while no one would advance the theory seriously that a professional man should yield up a portion of his annual income to support the local government, yet all will agree that if he invests a part of his earnings, it becomes capital to him and the investment should be taxed. 
So with real estate. It is the tangible expression of invested capital, and because it is tangible, a word which has the same root as touch and tax, it has become the target of the community collector. It represents the whole or a portion of the owner's worth and should bear its proportion of the cost of government. Under annual reassessment, if it increases in value, the community gets the taxable percentage of the increment plus the capital invested; if, on the other hand, it depreciates in value, the owner is correspondingly worth less, and the shrinkage is evidenced by the amount of the assessment. But he is still paying his fair portion of the burden of government.

This argument is sound and has its basic thought in equality, which is equity. The inequality does not lie in the amount of the increment, but in the lack of the necessary machinery to properly appraise it, and the machinery to review the appraisement from time to time so that the owner is paying on its present market value, and not on a value fixed at a remote period.

Now assuming the constitutional provision is sound that the individual must pay on his worth and not on his earning power or the earning power of his capital directed by his energy, the practical question for the municipality is: What is the individual worth? To ascertain this, that which he owns must be competently appraised; and to competently appraise and review the appraisement, the taxing power must provide the means; and when this means is found and furnished, if it is competent and sufficiently active, the fair market value of the wealth of the subject, whether expressed in unimproved land or real estate or certain forms of personalty, may be annually ascertained, and uniformly and equitably taxed; thus yielding to the support of the local community a percentage of the original capital, plus the annual increment, less the annual shrinkage.

In the judgment of the writer this is all the community has a right to demand. And if the demand is fairly met, the community will be more prosperous, and the burden of taxation more evenly distributed and less onerous, than by special taxation of the brains and energy of certain individuals who happen to be successful money makers.

Will annual reassessment be a fair substitute for the increment $\operatorname{tax}$ ?

In the larger cities values are constantly changing, due in part to the growth of the city, the shifting of utilities, and the caprices of the citizens. Real estate has cycles of prosperity and adversity, and 
values rise and fall with the market. If values were solely the expression of the number and buying power of the community, they should gradually rise as the community grows. But those of us who have real estate holdings are sadly aware of the fact that need, desire and caprice constantly change values.

These changes are most rapid in the commercial centres and in the suburbs, and are generally downward in the intermediate points. To properly appraise values so that an equitable basis of assessment including the increment may be had, it is, in the writer's judgment, necessary that the real property in all large cities, and such personal property as may be locally the subject of taxation by law, should be annually appraised.

While the average thinking man will generally approve annual reassessment in any community where the annual increment is more than the cost of ascertaining its value, there are a number of questions arising as to how unimproved land should be appraised for local taxation. Any number of plausible and ingenious arguments have been advanced whereby land which produces no return in rent should be appraised at a different value or taxed at a different rate from improved property.

A number of cities have urban, suburban and rural rates of taxation, with tests of classification, others with a uniform rate have special or partial exemption features for vacant land. All these features are, in the judgment of the writer, wrong in spirit. The object of the taxing power is to secure revenue, its desire should be to secure it by taxing value and not earnings. While the rent an improved property will produce is, if properly capitalized, a safe guide as to the value of the whole, and where the improvements are adequate to the site, the difference between the cost of the improvement, less deterioration and the value of the whole, will fairly represent the land value, still if the value is in unimproved real estate, it is because it has a potential earning power if improved, and present realization value if sold. If the citizen owns $\$ 10,000$ worth of real estate, it does not make any difference whether it is in a downtown warehouse or an undeveloped suburb, the rate and assessment, should be the same.

The argument that the owner of unimproved land gets no revenue, and therefore should have a special rate, creates the single taxer and increment taxer. If the unimproved real estate is worth 
its appraised value, it is because the seller may in normal times under normal conditions realize on it. And if he does not realize, it is because he believes that it is going higher than interest on his present realization value, which is an increment.

Another subtle argument which the owner of unimproved land advances is, that if land is taxed at its full value, it brings about an over-improvement of site, creating ruinous competition in improved properties, causing vast wastes in capital, and the withdrawal of capital from real estate investment, unusual vacancies with attendant demoralization.

This is undoubtedly true where the community undertakes to penalize land out of use by making it the sole object of taxation Thus it is now becoming apparent in so called "single tax communities" that the penalization of land and the exemption of improvements have created an over-production of improved properties, not only forcing values downward, but causing the withdrawal of capital from real estate. And here let us state parenthetically, without any attempt to be academic, that there is no such thing as the survival of the fittest in real estate. When values are depressed by reason of over-production, in warehouses, all warehouse property is affected. When there is an over-production of shops, all shop property is affected, and on through the list. Too many properties to choose from makes a choice uncertain, and the purchaser withdraws from the market.

But the practical answer to this argument lies in being able to distinguish the real value. Where a vacant lot in the heart of the city is held out of use, it cannot be because of over-production, but because the owner is unwilling to improve it, unable to satisfy his mind as to how to improve it, or because the increment is in his judgment more than the increment would be plus the interest on the invested capital to improve. Such an owner should pay on real value. Where there is a doubt as to whether the location of the land is such that its highest utility is apparent, this will be reflected in its true value, and should be treated accordingly. Thus in a semiresidence district in a transition state, if the improvements have anything like a construction value, the land has a residence value only, and if the land has a business value, the improvements are obsolete. In either case the whole will fairly balance and should be so considered. But to force a business value on the lot, and at the 
same time carry a construction value on the improvement is manifestly unfair. Hence we see in all the large cities this particular class of property bearing more than its share of the taxable burden, requiring skill and judgment in the assessor to differentiate. There is a section, however, in every large city where the question of local taxation is acute, and conditions are hard to meet.

So long as a tract of rural land remains undeveloped, it should not be appraised for taxation for more money than it is reasonably worth as undeveloped property, notwithstanding that the adjoining tract may be developed. To make this clear, if Blackacre farm sold three years ago at $\$ 1,000$ per acre, and the owner laid it out into building lots and sold out at the rate of $\$ 5,000$ per acre to one hundred customers after three years of hard work and the expenditure of large sums in development, Longacre, the adjoining tract, is not worth over $\$ 1,000$ per acre plus the increment which attaches by the development of Blackacre, which may not be an increment, but indicates that the demand for lots was not up to the supply; notwithstanding that single acres might be marketed for $\$ 3,000$.

In many cities the student of taxation problems will find on one side of the road assessments at $\$ 1,000$ per acre on undeveloped land, and on the opposite side assessments around $\$ 4,000$ per acre on building lots, which would apparently be entirely out of harmony. But the average suburban development must be marketed in lots at 500 per cent profit over original cost, to provide for loss of area in streets and alleys, cost of introducing the various services, providing streets, drainage, advertising and selling cost, interest on the investment and a hundred little things which creep into the cost of marketing a suburb.

A still more difficult problem than the above confronts the assessor, and that is the appraisement of land in bulk in the developer and the individual lot owner in the same subdivision.

So long as Blackacre is a farm it has an acreage value. As soon as streets are laid out and the lots staked off, it becomes a subdivision; a pioneer price is placed on each lot, and a number of the choice lots marked sold whether they have been sold or not. The assessor has no difficulty in gotting the asking price, and institutes comparisons with adjacent developments. He may reach a conclusion that the lots are priced too high and will not bring the asking price, and will turn them in at say 70 per cent. The lots are figured at 500 per 
cent profit and the owner has concluded that he will be ten years working out. He promptly appeals, and makes this argument:

It is true I paid $\$ 1,000$ per acre for this farm, and that $I$ have sold five lots out of two hundred at $\$ 5,000$ per acre. Notwithstanding this profit I will lose money unless I sell out all my holding in ten years. But if I sell out now I will make money at $\$ 3,000$ an acre notwithstanding my expenditures. And while I want a thousand dollars for one fifth of an acre of land, I will sell you all I have at $\$ 3,000$ per acre, or 300 per cent on my original investment, which would cut down this assessment to 60 per cent of the sale price of the lots.

Now how are you going to meet it? You cannot. If the land is worth $\$ 1,000$ per acre undeveloped, and the owner after spending $\$ 1,500$ per acre on it is willing to sell out at $\$ 3,000$, it is because as a wholesale proposition that is its value. Therefore the assessor will start in at, say $\$ 3,000$, and each year advance the assessment as the lots are sold.

Such a treatment is, in the writer's judgment, the only equitable appraisement. It rarely happens that suburban land is advantageously marketed without large expenditures in buildings to establish the atmosphere. These establishments are frequently sold to people who are desirable socially at large monetary losses, which losses are capitalized up against the remaining lots. While a number of developers think a low assessment a desirable asset in marketing the land, it often presents to the enquiring mind of the prospective purchaser the question that either the assessor does not know what he is doing or the purchaser is getting trimmed unmercifully, and when he reaches the latter conclusion, he is no longer a prospective purchaser.

While these values are equalizing themselves, the individual assessments on the lots bought and improved should not be materially changed, until the whole subdivision may be said to be fairly established, and then increase them uniformly at intervals, until the full value of the individual lots has been reached, which will be usually around or less than the original selling value. The equality expert goes through the books and points the finger of scorn at the supposed under assessments. But are they under assessments?

The individual lot buyer is to a certain extent the tool of the promoter, and if there are not enough of them to establish the particular suburb in a reasonable time, the values recede, and the developer cuts his prices to quicken the market. Thus the pioneer 
purchaser must either help the developer or the developer will undersell and thus cheapen the pioneer's purchase. And if he takes this risk in becoming a pioneer, can his holding be said to have a market value equal to its purchase price, until approximately all the lots are sold and the property developed beyond the experimental stage?

The last feature of the subject we can touch on in this article, is the question of land contours, soil formations, grades, etc. If the expression of value is fixed by the sale of one or more lots in a suburb, the character of the land is important; and the assessor, in seeking to value the lots uniformly, must take these features into consideration. A gentle terrace a few feet high may be considered desirable. If the land has to be filled up, the fair cost of filling the same should be deducted, plus the cost of the extra foundation of a building reasonably adapted to the lot, if it be found that the fill was below foundation depth. If on the other hand there is a hill with an outcropping of rock, which cannot be treated, the question of moving the rock must be considered. Where the lots run to a swamp, they must be separately treated, and it frequently happens that such lots are practically valueless in low priced subdivisions. We have seen adjoining lots of the same shape and size, with vastly different values per foot, because of these minor factors. So that uniformity in assessment expressed by the foot or acre must be the expression of value, and not the answer to a sum in arithmetic.

In conclusion, most real estate owners are community grouches, and a happy taxpayer as rare as a genuine Rembrandt. He feels the burden which is ever increasing and the tendency of modern government to exempt all forms of personalty and thus double the burden of real estate.

No one would think of buying a piece of real estate, which is not a subject of larceny, without properly recording the deed. But because of lax laws valuable personal securities, which could be stolen, are unregistered and their owners often unknown. Against this the argument goes to heaven, that business is the life of the government, and taxation at the source is taxing business.

But here comes the inexorable law of supply and demand. The cotton lies unpicked on the fields, because there is an over-production of cotton. From the homes of the poor comes the wail, "we cannot afford to buy meat." Why? Because the land is too high to be utilized for cattle production. The farmers have found new utilities for the 
land; the country is being divided into building lots and truck farms; arid plains are being irrigated into orchards; apples are worth a fifth of a cent to the producer and 3 to 5 cents to the consumer, the consumer and the producer are both groaning under the weight of taxation, and the railroads carrying so much water that they have no room for apples, and three or four middlemen untaxed making a profit out of that innocent apple before it gets to the 3 cent buyer.

Let the taxation theorist who sees one side boil it down to its final analysis, looking at it from every angle, and be will find that the ultimate security of the bulk of the wealth of the country is in real estate, that the fictitious or paper wealth of the country is the capitalization of the individual effort to utilize either the forces of nature or the real estate, expressed in franchises, as well as actual ownership of land and its appurtenances; that the fictitious wealth is more than the actual; that generally it is untaxed, but generally carries control; that this control is not only a holding force but an influencing force, not infrequently a corrupting force; that the taxing power requires other sources of revenue than real estate; that the so-called unearned increment is a mere cipher in the unthinkable figures which express the wealth of this country; that, as real estate is the only tangible expression of wealth, its value must be stablized, or the country will go the way of ancient Rome; that land values may only be kept up by the lure at least of an increment more than the average interest yields; that before you attempt to tax the increment, you must first determine that it is unearned, which is a very difficult thing to do, and that to tax it is to advertise it, to advertise it is to encourage a gambling scheme, for, viewed from its rosiest aspect, it is a gamble; and lastly, that real estate speculation does not increase values, but tends to make them uncertain; and a national depression in real estate will have as disastrous an effect on the body politic as a whole as an over-production of cotton or a scarcity of beef. 